\title{
When entrepreneurs raise entrepreneurs
}

\author{
Nadine Kammerlander (WHU - Otto Beisheim School of Management) \\ Larissa Leitner (WHU - Otto Beisheim School of Management)
}

KEYWORDS: Family Business, Startups.

Family businesses are the backbone of many economies. However, many potential successors of family businesses decide not to join the family business at first, but to become entrepreneurs themselves. According to a new study, about 25 percent of these potential successors decide to found their own company.

How can family businesses and the start-ups of the next generation successfully cooperate? We spoke to many entrepreneurs running family businesses and founders with a family business background in German-speaking countries, and found that many next-generation founders reported synergies between their start-up and the family business, which were equally fruitful for both companies. Through our research we discovered strategies that help those family businesses and startups cooperate and thrive.

\section{The 'my own path' generation}

Until a few years ago the next generation would typically join the family business immediately after completing their studies or apprenticeship. But the latest study on succession in family businesses shows that about 25 percent of family firm successors start their own company ${ }^{[1]}$. The urge to prove oneself, to build something from scratch, and to be independent from the family tends to be strong among younger family firm offspring. Having grown up in the environment of a family business adds pressure on the next generation. This pressure does not necessarily come from the family, but often from the next generation themselves.

Following into the footsteps of a successful family business can be a daunting prospect. However, the next generation also demonstrates an urge to emulate their predecessors. One founder told us: "Even though my company is smaller than the family business by a factor of six, I was able to build something by myself." Another next generation founder explained: "There are two aspects of success: financial success, and the success to have created something independently. The fact that I built this myself from scratch is more important to me than higher financial profits through continuation of the family company."

Nowadays, it is often no longer sufficient to simply be the successor of a family business in order to be accepted as its new leader. The next generation seeks legitimacy as a successor by recognition outside of the family business. Some have tried to gain experience at a large company, but find they are not happy because the of the complicated processes and policies of those large corporations. Therefore, founding their own company became more attractive: "Nowadays, you can't simply join the family business without having built something yourself. Establishing your own company really helps build respect among others." For another founder it was clear, that before joining his family business, he had to gain external legitimacy: "In the past [as a family member], you were automatically qualified to run your family company and no employee doubted that. In a much more global and egalitarian society today, that is no longer the case."

Most family business parents support the founding of the next generation start-up. Almost all of our interview partners told us that their family was interested and supportive in their ideas and business projects. Parents are proud when their children follow their entrepreneurial spirit. One founder told us: "They didn't tell me I should do something reputable or something safe. When I told them about my idea, they were super positive and just told me: Go for it!" Most families understood the desire of their children to be their own bosses, because most of them never experienced it in any other way either. Very often it was no big surprise for the parents when the next generation told them that they want to start their own business. A founder described it as: "I am the fifth generation of entrepreneurs in my family; for me self-employment is normal. Even as a child I knew that one day I would be self-employed."

Many members of the next generation start their own
Copyright (C) The Authors. Entrepreneur \& Innovation Exchange is published at EIX.org. This is an open access article under the terms of the Creative Commons Attribution-NoDerivs License, which permits use and distribution in any medium, provided the original work is properly cited and no modifications or adaptations are made. View EIX.org Authorship Terms at https://eix.org/terms
FamilyBusiness 
enterprises to gain skills that will help them lead the family firm later. This skill set very often includes experience in the digital world. The next generation is more focused on digital products and business models, while the family business itself might often still be oldfashioned and based on "bricks and mortar" business models. These new influences can help the family business attract fresh young talent and prepare for the future. The start-up, in contrast, can benefit from the established family business's various tangible and intangible resources.

\section{Real-life next gen example}

Verena Pausder is the 39-year old daughter of Rudolf Delius, who together with his brother Friedrich Wilhelm Delius, leads the family business DELIUS, now in its 9th generation. The business started in 1722 when Johann Caspar Delius founded a small linen trading house in the city of Bielefeld, Germany. Each generation took over the family-run business, changed and expanded business areas, adapted to industrial challenges and was able to create and maintain a renowned global company. For nearly three centuries the brand DELIUS has been known for its high-quality fabrics and its multifunctional fabric finish.

Former Delius member Verena Pausder is an entrepreneur herself. Instead of joining the family business, she started her first company, a Sushi restaurant chain, at the age of 19, and more start-up incorporations followed. She also co-initiated the nonprofit initiative, "START-UP TEENS," which aims to inspire schoolchildren to become entrepreneurs and teach them entrepreneurial thinking and acting. In 2012, she founded Fox \& Sheep, a Berlin-based start-up, which develops and distributes high-quality entertainment and learning apps for children aged 2-8 years. The apps, "Good Night Little Foresters" and "Petting Zoo," are bestsellers with over 18 million downloads worldwide. In December 2014, the toy manufacturer HABA, a third-generation family business itself, became the majority shareholder of Fox \& Sheep. Verena told us that having grown up in a family business helps her understand the needs of her family business investor much better because they are on the same page: "I feel like I'm going home when I go to their headquarters." In February 2016, together with HABA, Fox \& Sheep started to open digital studios where children of all ages can learn programming.

Sharing the same values as her family business, Verena created Fox \& Sheep with a long-term perspective in mind, not aiming for a quick financial exit. Even though she is busy leading her own company, Verena is still involved in her family business. The synergies between her start-up and the family firm are wide-reaching. Verena is still part of the supervisory board of Delius and always informed about the newest and most important strategic developments of the family firm. Her know-how in digital products helps the family firm to keep up with the competition because, given the industry of her start-up, she is engaged in both coding and artificial intelligence. In her regular business trips to the Silicon Valley, she immerses herself in new production methods and trends. This knowledge is transferred to the family firm, where she makes sure that the most relevant techniques are implemented. She describes the collaboration between her and her father as a continuous exchange of ideas. But she also benefits from her family firm's network, especially at the beginning of her career, where she had the chance to meet many interesting people. She regularly consults her father not only for strategic advice for her start-up, but also career guidance for herself. Moreover, her startup could rely on the family's resources, since the family office of Delius is invested in Fox \& Sheep.

When asked if one day she wants to take over her family business, she answered that it is still a feasible option for her, but not yet. She explained why she became an entrepreneur herself in the following way: "I think I am just unable to be employed; you experience leadership from day one in your life. The pursuit of freedom and independence and to be allowed to think freely, it is just in your genes."

While the example of Verena Pausder is a very successful one, the collaboration between next generation and family firm entrepreneurs does not always turn out successfully.

For instance, we talked to the son of a third-generation family-owned company who founded his own start-up in the same industry as the family business. The business model was similar to the family firm's; however, he applied a digital approach to it. At the beginning, he could profit from the know-how and the network of the family business. While at the beginning the support of the family and the family firms' employees was beneficial, at a certain point it just became too much. He did not have the freedom to make his own decisions and became more and more involved in the family firm. The 
founder felt pressured by his family to enter and take over the family-owned company. At a certain point, he claims to not have had enough time to lead his own startup. With no one taking care of the start-up, most of its outlets needed to be closed down.

So the question arises: what can family firms, their owners and successors do to make collaboration between the two companies successful and fruitful?

Based on the insights that we gained from discussions with many family firm owners and next generation founders, we identified the following recommendations.

\section{Recommendations for action}

These are the most important best practices for the older generation family firm entrepreneurs who want to support their children:

\section{A. Be critical, but only if you are asked.}

If the next generation asks family business entrepreneurs for advice or help, provide them with your candid opinion. Only providing positive feedback to the next generation doesn't help the start-up. However, too much advice or too much involvement might unnecessarily hamper the founder, as the example above showed. As a consequence, the next generation may feel controlled or not sufficiently trusted. Therefore, the most important rule seems to be: only give advice when asked.

\section{A. Never try to influence the start-up's direction.}

It is the responsibility, as well as the risk, of the next generation to become successful with their business. Attempts by the older generation to determine the startup's direction can harm the young business, the relationship between the family members, and ultimately even the family firm succession. For example, if the startup decides to move to a bigger city instead of staying in the rural area near the family firm, let it go and respect the decision. The next generation should lead their startups in the same free and independent manner that previous generations led the family firm.

\section{A. Standardize conditions for capital.}

Financial capital is one of the most important resources for a start-up. Very often, the family or the family firm provide the start-up with capital in different forms. In order to remain interesting for external investors, it is important that the conditions for this capital are the same as for external investors - for the start-up (e.g. interest rate), as well as for the family firm (e.g. shares).

Here are the most important best practices from our findings for next generation start-up founders:

\section{B. Record the use of resources and pay back - in any form you can.}

Many founders initially rely on the resources of the family firm. For example, the accounting department of the family firm helps with the start-up's tax declaration, or the law department supports in legal issues. The exchange of resources is quite natural in such settings. However, it is also dangerous because an excessive reliance on the family firm's resources might undermine the legitimacy and independence of the start-up and might also harm the family relationships. Hence, once the start-up is more mature, founders should think about reimbursement or returning the received resources in other forms. Practical examples of such "paybacks" might include support with the family firm's website, setting up online marketing, and/or assisting with attracting young talent.

\section{B. Make sure your business idea is able to withstand external feedback.}

Often families "blindly" support the ideas of their offspring, in particular when they are proud that their children want to follow their entrepreneurial role model. However, such feedback from the family is not always objective. Hence, to become successful, the business idea of the next generation needs validation not only from the family, but also from outside investors, potential customers or industry specialists.

\section{B. Acknowledge the experiences of the older generation, but go your own way.}

Negative dynamics and personal conflicts can substantially harm cooperation between the family firm and the start-up. The next gen founders need to acknowledge the achievements of the older generation, instead of denigrating their bricks and mortar businesses. At the same time, the older generation should not talk down the achievements of the next generation, in particular when revenues and profit are still small. Trust and respect for different approaches are key! 
Here are the most important best practices from our findings for start-up and family firm entrepreneurs:

\section{C. Know the potential risks.}

Every new company foundation comes along with risks. Only a small percentage of newly started businesses turn out successful. Therefore, family firms and startups that want to cooperate need to know about those risks and assess them diligently. The risks can include not only financial losses, but also damaged reputations and potential harm to family relations.

\section{C. Clearly speak about expectations.}

Expectations should be clear from the beginning - so all involved family (and non-family) members need to speak openly. Conflicts might arise if the start-up expects the family firm to serve as a customer or pilot client, but the family firm declines. Or if the older generation expects that the family firm can draw on "free" resources by the start-up (such as products or digital services), yet the start-up doesn't want to give up such revenues. To avoid those conflicts, both parties need to openly discuss expectations and address potential conflicts from early on.

\section{C. Be completely open in your communication.}

Honesty and openness are key to any fruitful collaboration - and this is even more important for cooperation among family members. For instance, the family members must be informed in a timely manner if the start-up is facing rough times, and the start-up needs to plan around whether it can or cannot expect further resources from the family firm in future. While a trust-based culture in general would allow for such openness, we often observed that the close connection between family members makes it difficult to bring bad news. So the family needs to find a way around such potential difficulties.

\section{C. Keep same terms as with external business partners.}

All agreements should be handled in the same ways as with external partners, for the start-up as well as for the family business. Treating the family firm/start-up cooperation as a business matter instead of a family matter helps head off severe conflicts. In particular, such an approach can balance the "mental bookkeeping" and minimize the chance that one of the partners will feel disadvantaged -- which usually leads to trouble.

\section{C. Have a common understanding of the start-up's long term goal.}

The future of the next gen's family business can vary. Some founders plan to sell their business; others aim to lead it for the long-term; still others have in mind to merge it with the family business later in time. While all options have pros and cons, it's important that the older generation of family firm owner/managers and the young founder generation have the same future options in mind. Diverging expectations about the future might cause conflicts: e.g., if the family firm invested resources into the start-up in the expectation that there will be a merger one day, whereas the founder plans for a financial exit.

\section{C. Identify and use synergies.}

A successful cooperation is reciprocal. If only the startup benefits from the family firm - or vice versa - the cooperation will not be sustainable. So it is important to identify how start-ups can benefit from the family firm: money, network access, infrastructure and advice from experienced experts are just few examples of how family firms can support the start-up. Conversely, the family firm can benefit from an external, out-of-the-box perspective, digital knowledge and access to new talent and new customer groups. Moreover, next gen's startups can often serve as useful "sounding balloons" for new business model ideas.

\section{C. Separate private and business matters!}

The family firm is central to business families and their identities. As such, it is no wonder that business opportunities are frequently discussed at the dinner table. However, to learn from the founding experience and gain legitimacy, next gen founders also need to keep control and the ultimate say about their business. As such, clear rules should be established about "business talk times" and "private talk times."

It's clear that younger members of business families often hone their skills by striking out on their own. Their parents' firms' resources and know-how can be important assets as they move forward. With the right synergies and cooperation, both generations can learn from each other and thrive. 


\section{Reference}

[1] PwC, (2017): Same passion, different paths: How the next generation of business leaders are making their mark. 
